\title{
HUBUNGAN ASPEK SOSIAL PEKERJAAN DAN KONDISI KINERJA DENGAN KEPUASAN KERJA PEGAWAI PUSKESMAS DI KABUPATEN KONAWE UTARA
}

\author{
Sri Rahayu ${ }^{1}$, La Ode Saafi ${ }^{2}$ Sanihu Munir ${ }^{3}$ \\ ${ }^{1,2,3}$ Program Studi Kesehatan Masyarakat STIKES Mandala Waluya Kendari \\ Email: raradentis@gmail.com
}

\begin{abstract}
ABSTRAK
Kepuasan kerja adalah kondisi pada tingkat yang dirasakan seseorang atas peranan atau pekerjaannya dalam sebuah organisasi. Jadi secara umum kepuasan kerja menyangkut psikologis individu didalam organisasi, yang diakibatkan oleh keadaan yang ia rasakan dari lingkungannya. PUSKESMAS sebagai pusat kesehatan masyarakat yang bersentuhan langsung dengan masyarakat merupakan ujung tombak pemerintah dalam bidang kesehatan. Selanjutnya aspek sosial adalah segala hasil aktivitas yang meliputi hubungan manusia dengan alam disekitarnya. Tujuan penelitian in adalah untuk mengetahui faktor-faktor yang berhubungan dengan kepuasan kerja pegawai Puskesmas dan menganalisis hubungan aspek sosial dalam pekerjaan dengan kepuasan kerja. Metode yang digunakan adalah mengginakan literature review yang dipadukan dengan metode Importance-Performance analysis (analisis tingkat kepentingan dan kinerja/kepuasan) dan kuantitatif. Hasil yang dicaoai adalah dapat mengetahui sejauh mana kepuasan bekerja pada PUSKESMAS berdasarkan pada kebijakan yang ada. Kesimpulan yang diperoleh bahwa terdapat Hubungan Aspek Sosial Dalam Pekerjaan Dengan Kepuasan Kerja Pegawai Puskesmas
\end{abstract}

Kata Kunci: PUSKESMAS, Kepuasan Kerja, Importance-Performance analysis

\begin{abstract}
Job satisfaction is a condition at the level felt by someone for their role or work in an organization. So in general, job satisfaction concerns the psychological individual in the organization, which is caused by the conditions he feels from his environment. PUSKESMAS as a public health center that is in direct contact with the community is the spearhead of the government in the health sector. Furthermore, social aspects are all the results of activities that include human relations with nature around them. The purpose of this research is to determine the factors associated with job satisfaction of Puskesmas employees and analyze the relationship between the social aspects of work with job satisfaction. The method used is to use a literature review combined with the ImportancePerformance analysis method (analysis of the level of importance and performance/satisfaction). The result achieved is to be able to know the extent of job satisfaction at the PUSKESMAS based on existing policies. The conclusion obtained is that there is a relationship between Social Aspects in Work and Work Satisfaction of PUSKESMAS Staff
\end{abstract}

Keywords: PUSKESMAS, Job Satisfaction, Importance-Performance analysis 


\section{PENDAHULUAN}

Dalam Peraturan Menteri Kesehatan Nomor 75 Tahun 2014 dinyatakan bahwa Pusat Kesehatan Masyarakat yang selanjutnya disingkat Puskesmas merupakan fasilitas pelayanan kesehatan yang menyelenggarakan upaya kesehatan perorangan tingkat pertama, dengan lebih mengutamakan upaya promotif dan preventif, untuk mencapai derajat kesehatan masyarakat yang setinggi-tingginya di wilayah kerjanya. Puskesmas berkewajiban melaksanakan kebijakan kesehatan untuk mewujudkan tujuan pembangunan kesehatan di wilayah kerjanya dalam rangka mendukung terwujudnya Kecamatan sehat. Disamping kewajiban tersebut Puskesmas juga berfungsi sebagai penyelenggara upaya kesehatan perseorangan dan upaya kesehatan masyarakat tingkat pertama dan juga sebagai wahana pendidikan tenaga kesehatan. (MENTERI KESEHATAN REPUBLIK INDONESIA, 2014)

Puskesmas sebagai ujung tombak pelayanan kesehatan diharapkan dapat menjadi penunjang keberhasilan program pemerintah. Di Puskesmas kepuasan kerja pegawai menjadi hal yang seharusnya memperoleh perhatian dari pihak manajemen Puskesmas, karena Puskesmas merupakan pusat pelayanan kesehatan perifer. Menurut Luthans dalam Suryadharma et al (2016) Salah satu sasaran penting dalam manajemen sumber daya manusia pada suatu organisasi adalah terciptanya kepuasan kerja, karena untuk memperoleh kinerja yang optimal dari pegawai, maka dipandang penting untuk memberikan kepuasan kerja yang pada akhirnya akan mendorong gairah kerja pegawai. (FATANA AMIRULLAH, 2010)

Kepuasan kerja dapat terlihat pada perasaan seseorang terhadap pekerjaannya, hal tersebut dapat tercermin dari sikap pegawai terhadap pekerjaan yang dilakukannya. Pegawai yang merasakan kepuasan terhadap apa yang didapatkannya maka pegawai tersebut akan cenderung memperbaiki dan meningkatkan kinerjanya. Hal sebaliknya ditunjukkan oleh pegawai yang memiliki kepuasan kerja yang rendah, mereka akan cenderung menganggap pekerjaannya merupakan suatu hal yang membosankan, karena pegawai tersebut bekerja dengan terpaksa. Pada kenyataannya masih banyak organisasi yang tidak mampu memberikan kepuasan kerja kepada pegawainya, sehingga hal tersebut dapat mempengaruhi kinerja dari pegawai itu sendiri (Arisandi Tri Hardiansyah, 2018).

Bertititik tolak dari uraian diatas kepuasan kerja pegawai merupakan suatu fenomena yang perlu dicermati oleh pimpinan organisasi terkhusus pimpinan Puskesmas.Kepuasan kerja pegawai berhubungan erat dengan kinerja pegawai. Pegawai Puskesmas yang merasa puas dengan pekerjaannya akan memiliki motivasi, komitmen pada puskesmas dan partisipasi kerja yang tinggi sehingga akan terus memperbaiki kinerja mereka dalam hal melakukan pelayanan kesehatan kepada masyarakat di tingkat pertama (Endang Sutisna Sulaeman, 2009).

Pegawai yang dalam bekerja tidak merasakan kenyamanan, kurang dihargai, dan tidak dapat mengembangkan segala potensi yang mereka miliki, maka secara otomatis pegawai tidak dapat fokus dan berkonsentrasi secara penuh terhadap pekerjaan yang dilakukannya. Ketidakpuasan kerja pegawai dapat diidentifikasi dari rendahnya produktifitas pegawai, tingginya kemangkiran dalam pekerjaan, dan rendahnya komitmen pada organisasi, yang pada akhirnya akan 
mempengaruhi kualitas pelayanan kesehatan yang diberikan kepada masyarakat di wilayah kerja Puskesmas (Tri Rini Puji Lestari, 2016).

Salah satu alasan yang diangkat dalam penelitian ini adalah untuk melihat aspek sosial masyarakat terkait pekerjaan dan kondisi kerja terkait dengan kepuasan saat melakukan aktifitas di PUSKESMAS sebagai ujung tombak layanan pemerintah dalam bidang keehatan. Sehingga peneliti akan melakukan studi literature berdasarkan dokumen yang ada pada PUSKESMAS untuk melihat secara rinci dan derail pokok permasalahan yang ada agar diberikan sokusi yang dapat mengghasilkan dokumen tertulis sebagai acaun dan panduan dalam bekerja untuk mencapai hasil yang diinginkan.

\section{METODE PENELITIAN}

Metode penelitian yang digunakan adalah penelitian kuantitatif.Dengan Rancang bangun penelitian ini menggunakan rancang bangun cross sectional study.Dimana analisis yang dilakukan terhadap variabel independen maupun variabel dependen dilakukan pada saat yang bersamaan dalam satu waktu (Imas Masturoh, 2018)

Populasi dan Sampel Populasi dalam penelitian ini adalah seluruh pegawai Puskesmas di Kabupaten Konawe Utara. Populasi dalam penelitian ini sebanyak 389 orang(MENTERI KESEHATAN REPUBLIK INDONESIA, 2014).Sampel adalah bagian dari jumlah dan karakteristik yang dimiliki oleh populasi tersebut(UNPAS, 2017). Sampel dalam penelitian ini dipilih berdasarkan kriteria inklusi dan eksklusi. Dimana kriterianya sebagai berikut :Kriteria Inklusi a. Pegawai Puskesmas baik Pegawai negeri sipil (PNS) dan pegawai kontrak daerah b. Bersedia untuk menjadi responden penelitian 2. Kriteria Eksklusi, Tidak bersedia untuk menjadi responden penelitianJumlah sampel dalam penelitian ini ditentukan berdasarkan perhitungan sampel yang dilakukan dengan menggunakan rumus Lemeshow yaitu sebagai berikut :

Keterangan :

$$
n=\frac{Z^{2}{ }_{1} \alpha_{2} p(1-p) N}{d^{2}(N-1)+Z^{2}{ }_{1} \alpha_{2} p(1-p)}
$$

$\mathrm{N}=$ Besaran populasi

$\mathrm{n}=$ Besaran sampel

$\mathrm{d}=$ Jumlah presisi $95 \%$ atau sig $=0,05$

$\mathrm{P}=$ proporsi subjek dari penelitian sebelumnya $=0,5$

$\mathrm{Z}=$ Tingkat kepercayaan $95 \%=1,96$

Tabel 1. Distribusi sampel menurut Puskesmas

\begin{tabular}{llcccc}
\hline No & \multicolumn{1}{c}{ Puskesmas } & $\begin{array}{c}\sum \\
\text { Pegawai }\end{array}$ & $\begin{array}{c}\text { Proporsi } \\
\text { Pegawai }\end{array}$ & $\begin{array}{c}\sum \\
\text { Sampel }\end{array}$ & Ket \\
\hline 1. & Puskesmas Matandahi & 25 & $6,43 \%$ & 12 & \\
2. & Puskesmas Lembo & 31 & $7,97 \%$ & 15 & \\
3. & Puskesmas Wawolesea & 21 & $5,39 \%$ & 11 & \\
4. & Puskesmas Andeo & 25 & $6,42 \%$ & 12 & \\
5. & Puskesmas Molawe & 25 & $6,42 \%$ & 12 & \\
6. & Puskesmas Tapunggaya & 19 & $4,88 \%$ & 10 & \\
7. & Puskesmas Asera & 18 & $4,63 \%$ & 9 & \\
\hline
\end{tabular}




\begin{tabular}{clccc}
\hline 8. & Puskesmas Langgikima & 9 & $2,45 \%$ & 5 \\
9. & Puskesmas Landawe & 14 & $3,60 \%$ & 7 \\
\hline 10. & Puskesmas Sawa & 27 & $6,94 \%$ & 13 \\
11. Puskesmas Lasolo & 33 & $8,48 \%$ & 16 \\
12. & Puskesmas Andowia & 26 & $6,68 \%$ & 13 \\
13. & Puskesmas Motui & 26 & $6,68 \%$ & 13 \\
14. Puskesmas Lamparinga & 10 & $2,57 \%$ & 5 \\
15. Puskesmas Wanggudu Raya & 20 & $5,14 \%$ & 10 \\
16. Puskesmas Langgikima & 7 & $1,80 \%$ & 4 \\
17. Pesisir & & & \\
18. Puskesmas Laronanga Pantai & 7 & $1,80 \%$ & 4 \\
19. Puskesmas Oheo & 12 & $3,08 \%$ & 6 \\
20. Puskesmas Lasolo Kepulauan & 4 & $1,03 \%$ & 2 \\
21. & Puskesmas Tetewatu & 6 & $1,54 \%$ & 3 \\
22. & Puskesmas Hialu & 8 & $2,06 \%$ & 4 \\
\hline & $\quad$ Jumlah & 389 & $3,86 \%$ & 8 \\
\hline
\end{tabular}

\section{HASIL DAN PEMBAHASAN}

Hasil penelitian ini menunjukkan bahwa dari 79 responden yang menjawab aspek sosial dalam pekerjaan kurang terdapat 50 responden (63\%) yang kepuasan kerjanya kurang, hal ini disebabkan karena pegawai Puskesmas di Kabupaten Konawe Utara dari aspek sosial dalam pekerjaan yaitu menyangkut hubungan antara pimpinan dan pegawai dan juga hubungan antara sesama pegawai kurang terjalin dengan baik yang mengakibatkan pegawai dalam bekerja kurang berinteraksi dengan pimpinan dan juga dengan sesama pegawai, dimana dalam suatu Puskesmas dibutuhkan interaksi yang baik antara pimpinan dan pegawai dan juga antara sesama pegawai dalam melakukan pekerjaan sehingga hasil dari pekerjaan yang dilakukan kurang maksimal dan hal inilah yang menyebabkan kepuasan kerja yang dirasakan oleh pegawai Puskesmas di Kabupaten Konawe Utara juga kurang.

Tabel 2. Distribusi Responden Berdasarkan Kelompok Umur Pegawai Puskesmas

\begin{tabular}{ccc}
\hline \multirow{2}{*}{ Kelompok Umur } & \multicolumn{2}{c}{ Jumlah } \\
\cline { 2 - 3 } & $\mathbf{n}$ & $\mathbf{\%}$ \\
\hline $22-28$ & 53 & $27 \%$ \\
$29-35$ & 98 & $51 \%$ \\
$36-42$ & 33 & $17 \%$ \\
$43-49$ & 10 & $5 \%$ \\
\hline Jumlah & 194 & 194 \\
\hline
\end{tabular}

Tabel 2 diatas menunjukkan bahwa, paling banyak responden berasal dari kelompok umur 29 sampai 35 tahun yaitu sebanyak 98 responden $(51 \%)$ dan yang paling sedikit berasal dari kelompok umur 43-49 tahun yaitu sebanyak 10 responde $(5 \%)$. 
Tabel 3. Distribusi Responden Berdasarkan Pendidikan Pegawai Puskesmas

\begin{tabular}{ccc}
\hline \multirow{2}{*}{ Pendidikan } & \multicolumn{2}{c}{ Jumlah } \\
\cline { 2 - 3 } & $\mathbf{n}$ & $\mathbf{\%}$ \\
\hline SMA & 10 & $5 \%$ \\
D1 & 1 & $1 \%$ \\
D3 & 111 & $57 \%$ \\
D4 & 9 & $5 \%$ \\
S1 & 60 & $31 \%$ \\
S2 & 3 & $2 \%$ \\
\hline Jumlah & 194 & $100 \%$ \\
\hline
\end{tabular}

Tabel 3.diatas menunjukkan bahwa dari 194 responden, paling banyak berpendidikan D3 sebanyak 111 responden (57\%) dan yang paling sedikit yaitu yang berpendidikan D1 sebanyak 1 responden (1\%).

\section{Hubungan Aspek Sosial Dalam Pekerjaan Dengan Kepuasan Kerja Pegawai}

Faktor sosial dalam pekerjaan menurut (DWI SATIYONO, 2012) merupakan hal yang berkaitan dengan hubungan yang terjalin antara pimpinan dan pegawai dan juga hubungan antara sesama pegawai. Hubungan kerja yang dimaksudkan dalam hal ini menyangkut hubungan yang terjalin di sekitar tempat bekerja(TITIS MELANI, 2010)

Tabel 4. Hubungan aspek social dengan kepuasan kerja pegawai

\begin{tabular}{|c|c|c|c|c|c|c|}
\hline & & & \multicolumn{3}{|c|}{ Kepuasaan Kerja } & \multirow[b]{2}{*}{ Total } \\
\hline & & & Kurang & Cukup & Baik & \\
\hline \multirow[t]{9}{*}{ Aspek Sosial Dalam Bekerja } & Kurang & Count & 50 & 22 & 7 & 79 \\
\hline & & Expected Count & 28.5 & 29.7 & 20.8 & 79.0 \\
\hline & & \% within Aspek Sosial Dalam Bekerja & $63.3 \%$ & $27.8 \%$ & $8.9 \%$ & $100.0 \%$ \\
\hline & Cukup & Count & 12 & 41 & 8 & 61 \\
\hline & & Expected Count & 22.0 & 23.0 & 16.0 & 61.0 \\
\hline & & \% within Aspek Sosial Dalam Bekerja & $19.7 \%$ & $67.2 \%$ & $13.1 \%$ & $100.0 \%$ \\
\hline & Baik & Count & 8 & 10 & 36 & 54 \\
\hline & & Expected Count & 19.5 & 20.3 & 14.2 & $\overline{54.0}$ \\
\hline & & $\%$ within Aspek Sosial Dalam Bekerja & $14.8 \%$ & $18.5 \%$ & $66.7 \%$ & $100.0 \%$ \\
\hline \multirow[t]{3}{*}{ Total } & & Count & 70 & 73 & 51 & 194 \\
\hline & & Expected Count & 70.0 & 73.0 & 51.0 & 194.0 \\
\hline & & $\%$ within Aspek Sosial Dalam Bekerja & $36.1 \%$ & $37.6 \%$ & $26.3 \%$ & $100.0 \%$ \\
\hline
\end{tabular}

Dari 79 responden yang menjawab aspek sosial dalam pekerjaan kurang terdapat 22 responden (28\%) dengan kepuasan kerja cukup dan 7 responden $(9 \%)$ dengan kepuasan kerja baik. Hal ini disebabkan, walaupun pegawai Puskesmas di Kabupaten Konawe Utara memiliki hubungan yang kurang terjalin dengan baik antara pimpinan dan pegawai ataupun dengan sesama pegawai, akan tetapi para pegawai Puskesmas masih tetap melakukan pekerjaannya dengan baik sebagai bentuk rasa tanggung jawab terhadap profesinya, sehingga hal inilah yang menyebabkan walaupun aspek sosial dalam pekerjaannya kurang akan tetapi kepuasan kerjanya dalam kategori cukup dan baik. 
Dari 61 responden dengan aspek sosial dalam pekerjaan cukup terdapat 12 responden $(20 \%)$ yang menyatakan kepuasan kerja kurang, salah satu hal yang menjadi penyebabnya dikarenakan adanya hubungan yang terjalin dengan baik antara sesama pegawai Puskesmas dalam melakukan pekerjaannya sehari-hari di Puskesmas akan tetapi tidak disertai adanya hubungan yang terjalain dengan baik antara pegawai dan pimpinan Puskesmas. Hal inilah yang menyebabkan kepuasan kerja pegawai masuk dalam kategori kurang.

Sedangkan dari 54 responden yang menyatakan aspek sosial baik terdapat 8 responden (15\%) yang menyatakan kepuasan kerja kurang, bagi kebanyakan pegawai Puskesmas, selain bekerja juga dibutuhkan interaksi sosial dengan sesama pegawai, oleh sebab itu dengan memiliki rekan kerja yang ramah, terjalinnya hubungan kerja yang baik, dapat diajak bekerja sama dan rasa persatuan yang kuat akan menjadikan seorang pegawai memiliki kepuasan kerja yang baik.

Hasil analisis data menunjukan adanya hubungan antara aspek sosial dalam pekerjaan dengan kepuasan kerja pegawai Puskesmas di Kabupaten Konawe Utara.Hal ini sejalan dengan penelitian yang dilakukan oleh (A.A.WAHYU PRADNYANA, 2013) yang berjudul analisis tingkat kepuasan kerja karyawan di UD Padma Sari, yang mengatakan bahwa aspek sosial dalam pekerjaan berpengaruh terhadap kepuasan kerja. Aspek sosial dalam pekerjaan dalam penelitiannya masuk dalam kategori tidak puas, dimana hal tersebut diakibatkan para pekerja pernah berselisih paham dengan teman kerjanya baik perbedaan pendapat maupun sikap yang kurang bersahabat yang ditunjukkan oleh teman kerjanya (A.A.WAHYU PRADNYANA, 2013)

\section{Hubungan Kondisi Kerja Dengan Kepuasan Kerja Pegawai Puskesmas}

Kondisi kerja adalah keadaan material atapun psikologis yang ada ditempat kerja (A M.C.Mamesah., 2016). .Hal ini juga bila ditelaah lebih jauh dikarenakan secara kumulatif kepuasan yang dirasakan oleh responden terhadap kondisi kerja tersebut cenderung mengarah pada kondisi lingkungan fisik, seperti fasilitasfasilitas yang ada dan bentuk sarana lainnya. Hasil pengamatan peneliti, secara infrastruktur dan fasilitas yang ada pelaksanaan kegiatan - kegiatan pelayanan kesehatan di puskesmas tempat responden ini bekerja sudah memberikan gambaran yang baik dan sesuai dengan kebutuhan pegawai dan konsumen, akan tetapi tidak tersedianya fasilitas - fasilitas fisik seperti tidak adanya pendingin ruangan hingga sering terjadinya lampu padam juga turut mempengaruhi kepuasan kerja responden ini. Kepuasan kerja dapat tercermin dari perasaan seseorang terhadap pekerjaannya.Hal ini nampak dalam sikapnya terhadap pekerjaan dan segala sesuatu yang dihadapi di lingkungan kerjanya (Putranto et al., 2013). Hal ini juga terlihat hasil uji chi square diperoleh nilai hitung lebih besar dari $x^{2}$ tabel yakni $(49,963>9,488)$. Hal ini menunjukan adanya hubungan antara kondisi kerja dengan kepuasan kerja pegawai Puskesmas.

Dari 69 responden dengan kondisi kerja cukup terdapat 17 responden $(25 \%)$ yang menyatakan kepuasan kerja kurang, sedangkan dari 71 responden yang menyatakan kondisi kerja baik terdapat 15 responden (21\%) yang menyatakan kepuasan kerja kurang. Hal ini disebabkan karena faktor lain diantaranya adalah tidak sebandingnya antara beban kerja dengan gaji yang diterima, tidak adanya apresiasi dari pimpinan terhadap prestasi kerja, tidak adanya kesempatan dalam 
pengembangan karir dan kesempatan untuk maju. Hasil wawancara mendalam peneliti dengan responden ini juga diketahui bahwa responden ini merupakan tenaga honorer akan tetapi seringkali beban kerja yang diterima responden ini lebih banyak dibandingkan dengan pegawai negerinya. Penelitian yang dilakukan pada karyawan di Rumah Sakit Nur Hidayah Bantul menunjukkan hal yang sama, dimana aspek pekerjaan serta kesempatan mendapatkan promosi jabatan dapat mempengaruhi kepuasan kerja perawat (Ahmad Ahid Mudayana 2012).

Tabel 5. Hubungan Kondisi Kerja Dengan Kepuasan Kerja Pegawai Puskesmas

\begin{tabular}{|c|c|c|c|c|c|c|}
\hline & & & \multicolumn{3}{|c|}{ Kepuasaan Kerja } & \multirow[b]{2}{*}{ Total } \\
\hline & & & Kurang & Cukup & Baik & \\
\hline \multirow[t]{9}{*}{ Kondisi Kerja } & Kurang & Count & 38 & 14 & 2 & 54 \\
\hline & & Expected Count & 19.5 & 20.3 & 14.2 & 54.0 \\
\hline & & $\%$ within Kondisi Kerja & $70.4 \%$ & $25.9 \%$ & $3.7 \%$ & $100.0 \%$ \\
\hline & Cukup & Count & 17 & 35 & 17 & 69 \\
\hline & & Expected Count & 24.9 & 26.0 & 18.1 & 69.0 \\
\hline & & $\%$ within Kondisi Kerja & $24.6 \%$ & $50.7 \%$ & $24.6 \% 1$ & $100.0 \%$ \\
\hline & Baik & Count & 15 & 24 & 32 & 71 \\
\hline & & Expected Count & 25.6 & 26.7 & 18.7 & 71.0 \\
\hline & & $\%$ within Kondisi Kerja & $21.1 \%$ & $33.8 \%$ & $45.1 \% 1$ & $100.0 \%$ \\
\hline \multirow[t]{3}{*}{ Total } & & Count & 70 & 73 & 51 & 194 \\
\hline & & Expected Count & 70.0 & 73.0 & 51.0 & 194.0 \\
\hline & & \% within Kondisi Kerja & $36.1 \%$ & $37.6 \%$ & $26.3 \% 1$ & $100.0 \%$ \\
\hline
\end{tabular}

\section{Hubungan Pengawasan Atau Supervisi Dengan Kepuasan Kerja Pegawai Puskesmas}

Pengawasan atau supervisi merupakan suatu proses kegiatan yang dilakukan oleh pimpinan secara sistematis untuk membandingkan, memastikan dan menjamin bahwa tujuan dan sasaran serta kegiatan suatu organisasi terlaksana dengan baik sesuai dengan standar, rencana, instruksi dan ketentuan-ketentuan yang telah ditetapkan organisasi, serta mengambil tindakan perbaikan dan pencegahan yang diperlukan guna pemanfaatan sumber daya yang paling efektif dan efisien (WIDIA AGUSTINA, 2014).Hasil penelitian ini menunjukkan bahwa dari 46 responden yang menjawab pengawasan atau supervisi kurang terdapat 28 responden $(61 \%)$ yang kepuasan kerjanya kurang.Hal ini menggambarkan bahwa bahwa pengawasan merupakan salah satu faktor yang dapat mempengaruhi kepuasan kerja seorang pegawai.

Dari 46 responden yang menjawab pengawasan atau supervisi kurang juga terdapat 10 responden $(22 \%)$ cukup dan 8 responden (17\%) baik.Hal ini disebabkan karena responden masih diberikan kesempatan untuk memberikan masukan yang berguna untuk perkembangan dan kemajuan Puskesmas walaupun masukkan yang diberikan tidak mendapatkan respon langsung dari pimpinan.Selain itu suasana kekeluargaan yang tercipta dalam lingkungan kerja membuat responden merasa nyaman dan betah bekerja walaupun kompensasi yang diberikan tidak sesuai dengan beban kerja.Jarak rumah yang dekat dengan puskesmas merupakan alasan responden betah bekerja di puskesmas. Hal ini sejalan dengan teori yang menyatakan bahwa kepuasan kerja dapat disebabkan karena keadaan kondisi lingkungan kerja yang dirasakan oleh seseorang serta 
kurangnya pilihan dalam memilih tempat kerja juga turut mempengaruhi keputusan seseorang tetap bekerja pada suatu organisasi (REGINA ADITYA REZA, 2010)

Tabel 6. Hubungan Pengawasan Atau Supervisi Dengan Kepuasan Kerja Pegawai Puskesmas

\begin{tabular}{|c|c|c|c|c|c|c|}
\hline & & & \multicolumn{3}{|c|}{ Kepuasaan Kerja } & \multirow[b]{2}{*}{ Total } \\
\hline & & & Kurang & Cukup & Baik & \\
\hline \multirow[t]{9}{*}{ Pengawasan atau Supervisi } & \multicolumn{2}{|c|}{ Kurang Count } & 28 & 10 & 8 & 46 \\
\hline & & Expected Count & 16.6 & 17.3 & 12.1 & 46.0 \\
\hline & & $\%$ within Pengawasan atau Supervisi & $60.9 \%$ & $21.7 \%$ & $17.4 \%$ & $100.0 \%$ \\
\hline & \multirow[t]{3}{*}{ Cukup } & Count & 15 & 48 & 16 & 79 \\
\hline & & Expected Count & 28.5 & 29.7 & 20.8 & 79.0 \\
\hline & & $\%$ within Pengawasan atau Supervisi & $19.0 \%$ & $60.8 \%$ & $20.3 \%$ & $100.0 \%$ \\
\hline & \multirow[t]{3}{*}{ Baik } & Count & 27 & 15 & 27 & 69 \\
\hline & & Expected Count & 24.9 & 26.0 & 18.1 & 69.0 \\
\hline & & $\%$ within Pengawasan atau Supervisi & $39.1 \%$ & $21.7 \%$ & $39.1 \%$ & $100.0 \%$ \\
\hline \multirow[t]{3}{*}{ Total } & & Count & 70 & 73 & 51 & 194 \\
\hline & & Expected Count & 70.0 & 73.0 & 51.0 & 194.0 \\
\hline & & $\%$ within Pengawasan atau Supervisi & $36.1 \%$ & $37.6 \%$ & $26.3 \%$ & $100.0 \%$ \\
\hline
\end{tabular}

\section{SIMPULAN DAN SARAN}

\section{Simpulan}

Adapun kesimpulan dalam penelitian ini, dapat dijabarkan sebagai berikut: Terdapat Hubungan Aspek Sosial Dalam Pekerjaan Dengan Kepuasan Kerja Pegawai Puskesmas, Terdapat Hubungan Kondisi Kerja Dengan Kepuasan Kerja Pegawai Puskesmas, Terdapat Hubungan Pengawasan atau Supervisi Dengan Kepuasan Kerja Pegawai Puskesmas

\section{Saran}

Adapun saran yang dapat diberikan dari hasil penelitian ini adalah sebagai berikut :Diharapkan bagi penelitian selanjutnya dalam melakukan penelitian dapat menjadikan hasil penelitian ini sebagai acuan dan melakukan penelitian terhadap faktor lain yang berhubungan dengan kepuasan kerja pegawai, Diharapkan bagi pihak Puskesmas dapat menjadikan pimpinan Puskesmas agar dapat lebih meningkatkan kepuasan kerja bagi Pegawai Puskesmas sehingga pelayanan yang diberikan kepada masyarakat juga dapat ditingkatkan, Diharapkan bagi Dinas Kesehatan dapat menjadikan hasil penelitian ini sebagai acuan untuk menilai sejauh mana kepuasan kerja pegawai Puskesmas di Kabupaten Konawe Utara dan dapat melakukan terobosan untuk meningkatkan kepuasan Kerja pegawai Puskesmas

\section{UCAPAN TERIMAKASIH}

Seluruh kepala PUSKESMAS Kabupaten Konawe Utara, Sulawesi Tenggara yang telah memberikan Informasi pada Penelitia ini. 


\section{DAFTAR PUSTAKA}

A M.C.Mamesah., L. K., V.P.K. Lengkong,. (2016). PENGARUH LINGKUNGAN KERJA, DISIPLIN KERJA, DAN LOYALITAS KERJA TERHADAP KINERJA KARYAWAN PADA LPP RRI MANADO. Jurnal EMBA, 4(3), 12.

A.A.WAHYU PRADNYANA, M. T. H., PUTU UDAYANI WIJAYANTI,. (2013). Analisis Tingkat Kepuasan Kerja Karyawan di UD.Padma Sari. E-Jurnal Agribisnis dan Agrowisata, 2(3), 9.

Ahmad Ahid Mudayana (2012). HUBUNGAN BEBAN KERJA DENGAN KINERJA KARYAWAN DI RUMAH SAKIT NUR HIDAYAH BANTUL KES MAS, 6(1), 5 .

Arisandi Tri Hardiansyah, A. A., Mila Santika, . (2018). KEPUASAN KERJA SEBAGAI FAKTOR TERBENTUKNYA SIKAP KERJA PEGAWAI NEGERI SIPIL KANTOR KECAMATAN KLAMPIS, BANGKALAN. Jurnal Universitas Trunojoyo Madura, 20.

DWI SATIYONO, T. B. (2012). Pengaruh Faktor Individual, Faktor Sosial, dan Faktor Utama Dalam Pekerjaan Terhadap Kepuasan Kerja (Studi Pada Staf Kantor PT. Sinar Pantja Djaja Semarang).

Endang Sutisna Sulaeman. (2009). KEPEMIMPINAN KEPALA PUSKESMAS DENGAN TEMPAT PERAWATAN DAN PENGARUHNYA TERHADAP KINERJA PEGAWAI PUSKESMAS DENGAN TEMPAT PERAWATAN DI KABUPATEN KUNINGAN JAWA BARAT. URNAL MANAJEMEN PELAYANAN KESEHATAN, 12(2).

FATANA AMIRULLAH, S. (2010). Faktor-Faktor Yang Mempengaruhi Kepuasan Kerja (Studi Pada Pegawai Administratif IKIP PGRI Semarang). 16.

Imas Masturoh, N. A. T. (2018). Metodologi-Penelitian-Kesehatan_SC R. Y. Priyati (Ed.)

MENTERI KESEHATAN REPUBLIK INDONESIA. (2014). PERATURAN MENTERI KESEHATAN REPUBLIK INDONESIA NOMOR 75 TAHUN 2014. Peraturan Kementerian Kesehatan.

REGINA ADITYA REZA. (2010). PENGARUH GAYA KEPEMIMPINAN, MOTIVASI DAN DISIPLIN KERJA TERHADAP KINERJA KARYAWAN PT Sinar Santosa Perkasa. Universitas Diponegoro Semarang, Semarang.

TITIS MELANI, S. (2010). Faktor - Faktor yang Mempengaruhi Kepuasan Kerja (Studi pada Karyawan Sekolah Tinggi Ilmu Farmasi"YAYASAN PHARMASI" Semarang). 22.

Tri Rini Puji Lestari. (2016). ANALISIS KETERSEDIAAN TENAGA KESEHATAN DI PUSKESMAS KOTA MAMUJU PROVINSI SULAWESI BARAT TAHUN 2014. Kajian, 21(1), 14.

UNPAS, R. (2017). Populasi Dan Sampel (pp. 14).

WIDIA AGUSTINA, L. B. (2014). DAMPAK PENGAWASAN DAN KEPUASAN KERJA DALAM MEMPENGARUHI DISIPLIN KERJA KARYAWAN PT. PERKEBUNAN NUSANTARA IV (PERSERO) MEDAN. JURNAL RISET AKUNTANSI DAN BISNIS, 14(2). 